\title{
Managing Natural Resources through Sustainable Environmental Actions: A Cross-Sectional Study of 138 Countries
}

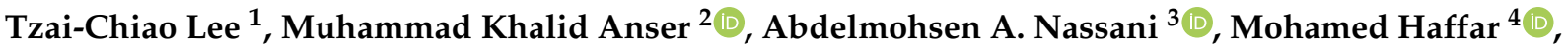 \\ Khalid Zaman ${ }^{5, *}$ and Muhammad Moinuddin Qazi Abro ${ }^{3}$
}

check for

updates

Citation: Lee, T.-C.; Anser, M.K.; Nassani, A.A.; Haffar, M.; Zaman, K.; Abro, M.M.Q. Managing Natural Resources through Sustainable Environmental Actions: A Cross-Sectional Study of 138 Countries. Sustainability 2021, 13, 12475. https://doi.org/10.3390/ su132212475

Academic Editor: Zachary A. Smith

Received: 3 October 2021

Accepted: 9 November 2021

Published: 11 November 2021

Publisher's Note: MDPI stays neutral with regard to jurisdictional claims in published maps and institutional affiliations.

Copyright: (c) 2021 by the authors. Licensee MDPI, Basel, Switzerland. This article is an open access article distributed under the terms and conditions of the Creative Commons Attribution (CC BY) license (https:// creativecommons.org/licenses/by/ $4.0 /)$.
1 School of Economics and Management, Chongqing Metropolitan College of Science and Technology, Chongqing 401331, China; lee2304361397@gmail.com

2 School of Public Administration, Xi'an University of Architecture and Technology, Xi'an 710000, China; mkhalidrao@xauat.edu.cn

3 Department of Management, College of Business Administration, King Saud University, P.O. Box 71115, Riyadh 11587, Saudi Arabia; Nassani@ksu.edu.sa (A.A.N.); mqazi@ksu.edu.sa (M.M.Q.A.)

4 Department of Management, Birmingham Business School, University of Birmingham, Birmingham B15 2TT, UK; m.haffar@bham.ac.uk

5 Department of Economics, University of Haripur, Khyber Pakhtunkhwa, Haripur 22620, Pakistan

* Correspondence: khalid.zaman@uoh.edu.pk; Tel.: +92-334-8982744

\begin{abstract}
Management of natural resources is pivotal for sustained economic growth-the increasing ecological footprints causing biocapacity deficit threaten the resource conversation agenda. The study identified the potential causes and consequences of natural resource depletion in a broad crosssection of 138 countries. Ecological footprints, international migrant stocks, industrial value-added, and population growth influenced natural resource capital across countries. The results show that ecological footprints, industrial value-added, and population growth are the detrimental factors of resource capital. In contrast, continued economic growth is helpful to conserve natural resources for future generations. The rise and fall in the natural resource degradation are evident in the wake of international migrants' stocks to support an inverted U-shaped relationship between them. The Granger causality inferences confirmed the one-way linkages, running from international migrant stocks, economic growth, and population growth to natural resource degradation. It verifies migrantsled, affluence-led, and population-led resource degradation. Ecological footprints Granger causes industrial value-added across countries. The forecasting estimates suggested that economic growth would likely to influenced greater in magnitude to resource degradation by its innovation shocks of $4.791 \%$, followed by international migrant stocks, population growth, ecological footprints, and industrial value added by their innovation shocks of $4.709 \%, 1.829 \%, 1.247 \%$, and $0.700 \%$, respectively. The study concludes that international migrant stocks should manage smartly, causing more resource degradation via a channel of increasing biocapacity deficit across countries.
\end{abstract}

Keywords: natural resource degradation; ecological footprints; international migrant stocks; population growth; industrial value-added; environmental index; robust least squares regression

\section{Introduction}

Natural resource management is essential for fueling economic activities at present and future generations. The massive deforestation, mineral resource depletion, energy and oil diminution, and coal combustions create difficulties in efficiently managing natural resources. There are numerous reasons for global resource degradation, i.e., population explosion, inadequate resource conservation knowledge, increased fuelwood consumption, improper financial market, natural and technical disasters, weakening resource extraction process, and lack of green financing [1-4]. The higher rate of natural resource depletion is found in many parts of the global world, including, Congo republic, i.e., $37.105 \%$ of GNI in 
the year 2019, followed by Timor-Leste (i.e., 27.949\%), Equatorial Guinea (i.e., 27.600\%), Angola, Oman (i.e., 21.143\%), Azerbaijan (i.e., 16.778\%), Brunei Darussalam (i.e., 14.460\%), Gabon (i.e., 12.841\%), Chad (i.e., 12.192\%), and Iraq (i.e., 11.743\%) [5]. There is a high need to conserve natural resources for future generations to attain ecological sustainability.

Ecological footprints, massive population growth, and industrialization are considered chief factors of natural resource degradation [6,7]. The arable land in hectares assesses ecological footprints worldwide. The United States has a greater arable land in hectares as reported in 2018 , i.e., $1.58 \times 10^{8}$, followed by India, i.e., $1.56 \times 10^{8}$, Russia, i.e., $1.22 \times 10^{8}$, and China, i.e., $1.19 \times 10^{8}$. However, these countries safely managed natural resources. The reported countries with massive resource degradation do not primarily cause ecological footprints but inefficiently utilized their resources for future generations. The massive population growth further cumbersome the resource conservation agenda. As per 2019 estimates, Bahrain has a greater population growth rate, i.e., $4.468 \%$, followed by Niger, i.e., $3.794 \%$, Equatorial Guinea, i.e., 3.528\%, and Angola, i.e., 3.242\%. The increase in international migrant stocks creates more challenges, resulting in more economic and natural resources degradation. The United Arab Emirates and Qatar are accommodating more than $75 \%$ of international migrant stocks, as per the estimates of 2019. Bahrain, Jordan, and Oman economies also absorb more international migrant stocks among the globalized world [5].

The earlier studies extensively worked on the resource sustainability agenda and used multifaceted socio-economic and environmental factors to identify resource degradation's potential causes and consequences across countries. For instance, Nathaniel et al. [8] analyzed the role of natural resource degradation on the environmental sustainability agenda amidst human development, urbanization and globalization in a panel of Latin American and Caribbean countries. The results affirm that the development of human capital formation is helpful to promote sustainable urban development and minimize carbon emissions. On the other hand, urbanization and globalization damaged the United Nations green developmental agenda to escalate carbon emissions. The Pareto efficient situation can be existing by spending R\&D on human development that helps to raise innovative ideas for sustainable urban development and mitigating carbon emissions. Anser et al. [9] concluded that massive population growth hinders achieving financial and resource sustainability objectives due to the overuse of natural and economic resources. The environmental sustainability index can improve by controlling population growth, pandemic shocks, and increasing natural resource rents. Muhammad et al. [10] considered a panel of BRICS and other developed and developing nations from 1991 to 2018 to analyze the role of inbound FDI, natural resources, green energy sources, and the country's affluence on carbon emissions. The results affirm the pollution haven hypothesis for BRICS nations and developing countries, while it further substantiates the pollution halo hypothesis for developed countries. The resource curse hypothesis was validated as an inadequate natural resource management jeopardy for the natural environment. The green energy sources played a vital role to achieve sustainability agenda, which further improves resource capital across countries. Bergius et al. [11] argued that investment in the green initiative would be helpful to raise significant natural and economic outcomes. Using the country case study of Tanzania, the study concluded that greenfield investment in large-scale farming practices and devoted a significant sum of money on environmental protection would be helpful to reach green developmental objectives. Ahmed et al. [12] analyzed China's country case study to evaluate the role of natural resources in achieving green developmental outcomes. The results show that ecological footprints are caused by the greater natural rents, leading to worsening environmental situations by continued economic growth and urbanization. The investment in human capital formation is the optimized solution to reduce the adverse negative environmental externalities to make the country's policies green and clean. Nguyen et al. [13] collected two different surveys data in 2013 and 2014 of 550 households in 30 rural villages in Cambodia to assess the healthcare vulnerability posing by increasing poverty and massive resource extraction. 
The results affirm that healthcare shocks persistently increase due to a higher incidence of poverty, intensifying by unsustainable extraction of natural resources. They optimize sustainable resource extraction techniques to care for the natural environment, providing opportunities to work to rural families to escape from poverty. Younis et al. [14] analyzed the environmental situation of BRICS economies from 1993 to 2018 by using financial factors, energy demand, urbanization, and trade openness. The results show that except Brazil, the stock market price index deteriorating environmental quality in a region. The other stated factors damaged the green developmental agenda that need to be corrected through sustainable technological transfers, renewable energy sources, and responsible production and consumption. Khan et al. [15] collected annual data of the USA from 1971 to 2016 to analyze the potential role of economic and natural resources on carbon emissions. The results show that green energy demand and natural resources decrease carbon emissions and ecological footprints. In contrast, population growth and non-renewable energy resources pressure environmental quality that exacerbates carbon emissions in a country. The management of natural resources and utilization of green energy sources is imperative for achieving green developmental agenda. Majeed et al. [16] concluded that the air quality level of the Gulf Cooperation Council economies could be improved by utilizing their natural resources, attaining energy efficiency in the production process, and economic globalization. Umar et al. [17] found that carbon emissions increase due to continued economic growth and resource curse; however, globalization helps improve China's environmental quality, leading towards environmental sustainability in the long run. Danish et al. [18] explored different determinants of ecological footprints in BRICS economies from 1992 through 2016. The results reveal that green energy sources, resource rents, and urban growth are positive factors that substantially decrease ecological footprints and support the environmental Kuznets curve hypotheses across countries. The resource balance played a vital role in reducing human pressure on arable land, supported by green and cleaner policies. Table 1 shows few more glimpses of earlier studies for the potential causes of natural resource degradation worldwide.

Table 1. Current Studies Identifying Causes and Consequences of Global Natural Resource Degradation.

\begin{tabular}{|c|c|c|c|c|c|c|}
\hline Authors & Time Period & Country & $\begin{array}{l}\text { Potential Factors } \\
\text { Affecting Environmental } \\
\text { and Natural Resources }\end{array}$ & & Consequences & Remedies \\
\hline Nassani et al. [19] & 1990-2019 & 10 countries & $\begin{array}{l}\text { Ecological footprints, } \\
\text { population growth, } \\
\text { insurance services, and } \\
\text { economic growth }\end{array}$ & - & $\begin{array}{l}\text { Mineral resources degradation. } \\
\text { Increasing adverse environmen- } \\
\text { tal externalities, and } \\
\text { compromised resource conserva- } \\
\text { tion agenda. }\end{array}$ & $\begin{array}{l}\text { Energy efficiency and trade } \\
\text { regulations help to conserve } \\
\text { mineral resources. }\end{array}$ \\
\hline Sun et al. [20] & 1995-2015 & 88 countries & $\begin{array}{l}\text { Energy demand, } \\
\text { international tourism, and } \\
\text { economic growth }\end{array}$ & $\begin{array}{l}- \\
- \\
-\end{array}$ & $\begin{array}{l}\text { Escalating resources led to carbon } \\
\text { emissions. } \\
\text { tourism led carbon emissions, and } \\
\text { energy led emissions. }\end{array}$ & $\begin{array}{l}\text { The resource curse } \\
\text { hypothesis needs to be } \\
\text { turned into a resource } \\
\text { blessing hypothesis by } \\
\text { adding renewable energy } \\
\text { resources, eco-tourism } \\
\text { factors, and responsible } \\
\text { consumption and } \\
\text { production in the resource } \\
\text { conversation agenda. }\end{array}$ \\
\hline Zaman et al. [21] & $\begin{array}{l}\text { 2010M01 to } \\
\text { 2018M12 }\end{array}$ & $\begin{array}{l}\text { Kingdom of } \\
\text { Saudi } \\
\text { Arabia }\end{array}$ & $\begin{array}{l}\text { Carbon tax, emissions } \\
\text { trading, and stringent } \\
\text { environmental regulations }\end{array}$ & - & $\begin{array}{l}\text { Exacerbating carbon emissions in } \\
\text { the ease of environmental policies. } \\
\text { Evidence of pollution haven hy- } \\
\text { pothesis, and } \\
\text { Increasing fossil fuel dependency. }\end{array}$ & $\begin{array}{l}\text { Solar electricity generation is } \\
\text { helpful to mitigate an } \\
\text { adverse impact of carbon } \\
\text { emissions in a combination } \\
\text { of imposing carbon pricing } \\
\text { policies and stringent } \\
\text { trade regulations. }\end{array}$ \\
\hline Gyamfi et al. [22] & 2000-2018 & 7 countries & $\begin{array}{l}\text { Fossil fuel combustions, } \\
\text { greenfield investment, and } \\
\text { economic growth }\end{array}$ & - & $\begin{array}{l}\text { Fossil fuel combustion derives } \\
\text { carbon emissions. } \\
\text { Country's affluence deteriorating } \\
\text { carbon neutrality agenda, and } \\
\text { Investment derives from } \\
\text { emissions-based production. }\end{array}$ & $\begin{array}{l}\text { Biomass energy demand is } \\
\text { pivotal to reach green } \\
\text { growth agenda that is less } \\
\text { sensitive to the environment } \\
\text { and achieving carbon } \\
\text { neutrality objectives. }\end{array}$ \\
\hline
\end{tabular}


Table 1. Cont.

\begin{tabular}{|c|c|c|c|c|c|}
\hline Authors & Time Period & Country & $\begin{array}{c}\text { Potential Factors } \\
\text { Affecting Environmental } \\
\text { and Natural Resources }\end{array}$ & Consequences & Remedies \\
\hline Du et al. [23] & 1975-2019 & China & $\begin{array}{l}\text { Women's autonomy, } \\
\text { financial development, } \\
\text { labour force employment, } \\
\text { and economic growth }\end{array}$ & $\begin{array}{l}\text { Locking women potential in man- } \\
\text { aging economic and environmen- } \\
\text { tal resources hampers economic } \\
\text { activities. } \\
\text { Unsustainable financing deterio- } \\
\text { rating economic and natural re- } \\
\text { sources, and } \\
\text { Labor market failures hamper } \\
\text { economic outcomes. }\end{array}$ & $\begin{array}{l}\text { Increasing women's } \\
\text { participation in economic } \\
\text { and resource markets help to } \\
\text { reduce environmental } \\
\text { failures, leading to improve } \\
\text { labour market outcomes and } \\
\text { sustained economic growth. }\end{array}$ \\
\hline Rehman et al. [24] & 1970-2019 & Pakistan & $\begin{array}{l}\text { Climatic variations and } \\
\text { agricultural productivity }\end{array}$ & $\begin{array}{l}\text { Climate change adversely af- } \\
\text { fected crops yield }\end{array}$ & $\begin{array}{l}\text { Adoption and adaptation of } \\
\text { resilient climate strategies } \\
\text { would be helpful to } \\
\text { increases agricultural yields. }\end{array}$ \\
\hline Anser et al. [25] & 1995-2018 & 90 countries & $\begin{array}{l}\text { Carbon pricing, inbound } \\
\text { FDI, population density, } \\
\text { fossil fuel combustion, } \\
\text { and country's affluence }\end{array}$ & $\begin{array}{ll}- & \text { Pollution haven hypothesis } \\
- & \text { fossil fuel-led emissions } \\
- & \text { population density escalating car- } \\
\text { bon emissions, and } \\
\text { - } & \text { economic growth led to emissions }\end{array}$ & $\begin{array}{l}\text { Progress in nuclear energy } \\
\text { and an adequate carbon tax } \\
\text { is helpful to mitigate } \\
\text { carbon emissions. }\end{array}$ \\
\hline Usman et al. [26] & 1990-2018 & 9 countries & $\begin{array}{l}\text { Information and } \\
\text { communication } \\
\text { technologies (ICTs) }\end{array}$ & $\begin{array}{l}\text { Unsustainable technologies ham- } \\
\text { per the green developmental } \\
\text { agenda. } \\
\text { Resource conservation agenda is } \\
\text { at risk due to a lack of knowledge } \\
\text { and technological spillovers. }\end{array}$ & $\begin{array}{l}\text { The use of asymmetric } \\
\text { impact of cleaner } \\
\text { technologies improves the } \\
\text { air quality level. }\end{array}$ \\
\hline Imran et al. [27] & 1975-2018 & Pakistan & $\begin{array}{l}\text { ICTs, economic growth, } \\
\text { poverty reduction, } \\
\text { urbanization, income } \\
\text { inequality, and carbon } \\
\text { emissions }\end{array}$ & $\begin{array}{l}\text { - Technology embodied emissions. } \\
\text { Technology-driven growth in- } \\
\text { creases poverty incidence. } \\
\text { Urbanization and income inequal- } \\
\text { ity led to emissions and poverty, } \\
\text { respectively. }\end{array}$ & $\begin{array}{l}\text { The use of green } \\
\text { technologies is helpful to } \\
\text { mitigate adverse } \\
\text { environmental externalities } \\
\text { and support pro-poor } \\
\text { growth policies in a country. }\end{array}$ \\
\hline Sharma et al. [28] & 1976-2015 & $\begin{array}{l}\text { A panel of } \\
\text { selected } \\
\text { emerging } \\
\text { Asian } \\
\text { countries }\end{array}$ & $\begin{array}{l}\text { Financial development, } \\
\text { economic growth, carbon } \\
\text { emissions, and energy } \\
\text { demand }\end{array}$ & $\begin{array}{ll}- & \text { Finance led emissions. } \\
- & \text { Affluence led emissions. } \\
- & \text { Energy augmented income esca- } \\
\text { lates emissions. }\end{array}$ & $\begin{array}{c}\text { The use of renewable energy } \\
\text { sources and green financing } \\
\text { help to improve environmental } \\
\text { quality. In a region. }\end{array}$ \\
\hline Cheng et al. [29] & $\begin{array}{l}\text { 2005Q1- } \\
\text { 2018Q4 }\end{array}$ & China & $\begin{array}{l}\text { Technological innovation, } \\
\text { affluence, carbon } \\
\text { emissions, and } \\
\text { globalization }\end{array}$ & $\begin{array}{ll}- & \text { Technology-driven growth. } \\
- & \text { Growth led emissions. } \\
- & \text { Globalization spurs carbon emissions. }\end{array}$ & $\begin{array}{l}\text { The country should need to } \\
\text { introduce an energy-efficient } \\
\text { system combination of green } \\
\text { energy sources and } \\
\text { technological innovation to } \\
\text { meet the pace of the } \\
\text { globalization era for } \\
\text { sustainable development. }\end{array}$ \\
\hline
\end{tabular}

Based on the cited literature, the study formulated the following research hypotheses, i.e.,

Hypothesis 1 (H1): Ecological footprints are likely to damage the resource conservation agenda due to overconsumption of natural resources.

Hypothesis $\mathbf{2}$ (H2): The international migrant stock is likely to show a rise and fall in natural resource degradation amid population growth, and

Hypothesis 3 (H3): Continued economic growth and industrialization are likely to exhaust natural resources to fulfil the international demand of their products to exports.

The contribution of the study is multifold. The study believes that it is the first study that used international migrant stock as the vital factor of causing biocapacity deficit, deteriorating resource conservation agenda. Moreover, the study used the second-degree polynomial of international migrant stock to observe the rise and fall in the natural resource 
capital to verify the 'resource Kuznets curve'. The ecological footprints are used as a proxy of biocapacity deficit, influenced by greater population and international migrant stocks that jeopardize natural resources. The nations affluence and industrial production further added in resource damage function to assess the economies strategies moving towards the United Nations resource conservation agenda. The earlier studies mainly limited their findings to a few countries and regions, limiting the generalizability of the policy implications to specific countries or regions [3-32]. The current study covered a wide geographical area and collected cross-section data of 138 countries that help to suggest more resource-oriented policies that can be generalized for the globalized world. A few studies used international migrant stock in the relationship between natural resource degradation and ecological footprints [33-35]. However, these studies are limited to explain the nonlinear causation of migrant stocks amidst resource capital and biocapacity deficit, which overcome these issues in a given study. The study added few controlled variables, including nations affluence, industrial production, and population growth, to understand their role in conserving resource capital, which is pivotal for long-term sustainable development.

Based on the study's contribution, the following three key research questions need to be answered, i.e., does international migrant stocks damage the resource conservation agenda by increasing the biocapacity deficit? The stated question is essential to understand the rise and fall in the natural resource capital by increasing international migrant stocks, causing greater ecological footprints across countries. The second research question is: to what extent population growth is responsible for consuming more natural resources for their livelihoods? The international agencies remain stressed to control enormous population growth that exhausts natural and economic resources, causing biocapacity deficit leading the world towards starvation. Finally, do the nations affluence and industrial value-added deteriorating resource conservation agenda fueling their economic production cycle? It is evident that fueling the economic process required more natural resources in production to fulfil the international demand of their products to earn foreign reserves. Responsible consumption and production are the way to conserve natural resources globally.

The following research objectives have been analyzed in the study, i.e.,

i. To examine the impact of international migrant stocks on natural resource degradation to verify the hump-shaped relationship between them.

ii. To analyze the role of increasing ecological footprints in conserving natural resources, and

iii. To investigate the impact of affluence, industrial production and population growth on natural resource degradation across countries.

The stated research questions and their objectives need to be checked through sophisticated statistical techniques. The robust least squares (RLS) regression estimator is the most suitable technique to handle cross-sections' structural shocks. Further, the Granger causality test and variance decomposition analysis (VDA) are used for analyzing causal inferences and forecasting estimates between the stated variables.

\section{Materials and Methods}

The study used natural resource degradation as a response variable. Ecological footprints, international migrant stocks, GDP per capita, industry value-added, and population growth were explanatory variables. The data of the studied variables are taken from World Bank [5]. The study covered a large cross-section of 138 countries for analysis. Table A1 in the Appendix A shows the countries list that is used in the analysis. The heterogeneous cross-section of countries allowed us to assess a more direct relationship between the candidate variables. The world faces enormous pressure from human activities on arable land, deteriorating precious species, biodiversity loss, and natural resource degradation. Further, an increased stock of international refugees' pressures arable land that exhausts economic and natural resources. The continued economic growth, massive population explosions, and higher industrialization worsen the environmental situation, which needs to be carefully tackled to achieve resource conservation agenda. Based on the stated issues, the study 
selected a large cross-section of countries to address the causes and consequences of natural resource degradation for sound policy formulation. Table 2 presents the variable's list and their measurements for ready reference.

Table 2. List of variables and Measurement.

\begin{tabular}{|c|c|c|c|c|}
\hline Variables & Symbol & Measurement & Data Period & Apriori Expectations \\
\hline $\begin{array}{l}\text { Natural Resource } \\
\text { Degradation }\end{array}$ & NRD & Resource depletion, \% of GNI & 2019 & - \\
\hline Ecological Footprints & EFPRNT & Arable land in hectares & 2018 & $\begin{array}{l}\text { Positive (negative } \\
\text { impact) }\end{array}$ \\
\hline $\begin{array}{c}\text { International Migrant } \\
\text { Stocks }\end{array}$ & IMS & \multirow{2}{*}{$\%$ of population } & \multirow[t]{2}{*}{2015} & $\begin{array}{l}\text { Positive (negative } \\
\text { impact) }\end{array}$ \\
\hline $\begin{array}{c}\text { Square of International } \\
\text { Migrant Stocks }\end{array}$ & SQIMS & & & $\begin{array}{c}\text { Negative (positive } \\
\text { impact) }\end{array}$ \\
\hline GDP per capita & GDPPC & Constant 2010 US\$ & 2019 & $\begin{array}{l}\text { Positive (negative } \\
\text { impact) }\end{array}$ \\
\hline $\begin{array}{l}\text { Industry value-added, } \\
\text { including construction }\end{array}$ & IND & $\%$ of GDP & 2019 & $\begin{array}{l}\text { Positive (negative } \\
\text { impact) }\end{array}$ \\
\hline Population Growth & POPG & Annual \% & 2019 & $\begin{array}{l}\text { Positive (negative } \\
\text { impact) }\end{array}$ \\
\hline
\end{tabular}

Source: World Bank [5].

\subsection{Hotelling's Principle of Exhaustible Resources}

Hotelling [36] principle of finite non-renewable resources has a special place in environmental and resource economics. Harold Hotelling discussed the pros and cons of excess extraction and the use of finite resources that jeopardize the consumption of future generations. The resource conservation agenda can be achieved to analyze and give weight to the price of exhaustible resources based on the current interest rate. The supplies of forests, minerals, and other exhaustible assets have limited that need to conserve by strong regulations to save them. Hotelling argued that there is a need to change people's thoughts about the high use of exhaustible assets because they consider these assets cheap for future generations. Thus, they can exploit their wishes. The imposition of government taxes on exhausting resources would likely give some sense of belonging to the natural assets to avoid cutting trees and sustainable extracting the resources to save for future generations. Hotelling's theory concluded that an owner of non-renewable resources should have a clear mind about how to sell and when to sell the resources in the hope of receiving a better price of the assets in the future. Several earlier studies used Hotelling's principle in evaluating the discounting price of natural resource assets to save precious assets and attain resource sustainability [37-42].

\subsection{Hotelling's Principle Extended View}

The study extended Hotelling's principle by using the following key variables, i.e.,

i. Natural Resource Degradation: The globalization era put many challenges and opportunities to excel in a competitive world by using their natural resources to acquire a competitive edge over the rest of the economies. The race-to-the-bottom hypothesis is merely visible in a globalization era where the nations' resources are overexploited instead of acquiring a few coins that are going down the economies in the long run when the resources vanish for the use of future generations. The need to restore economic beauty by preserving natural resources is the ultimate policy option to discount the future price of the resource assets [43,44].

ii. Ecological Footprints: The extensive human footmarks on arable land for economic activities exhaust many precious resource assets that need to be discounted for future 
generations. The increase in ecological footprints hampers the resource conservation agenda, which need to sustain through stringent environmental regulations. The owner of exhaustible resources needs to decide to sell all their resource assets presently or wait for next years to sell to acquire better prices. The conservation of resource assets can be viable when reducing ecological footprints on commodity markets [ 45 , 46].

iii. International Migrant Stocks: The increase of international refugees in many parts of the globalized world puts a burden on economic and natural resource markets that exhausts enormous rates. The pragmatic policies and intelligent decisions for managing international refugees would be helpful to restore natural resource capital for attaining sustainable development [47].

iv. Economic Growth: The continued economic growth hampers resource conservation on the cost of indulging in the globalization era. The local and international demand for natural resources used in exporting goods makes it difficult to achieve the green development agenda. The sustainable consumption and production of natural resources are the ultimate options to save their exhaustible resources for future generations $[10,48]$.

v. Industrialization: The structural shifts from traditional to modern society required extensive extraction of resource assets used in an industrial process to exports to other countries, creating a problem of resource scarcity. The optimum use of natural resources in production and firm legislations to protect the resource assets are the viable and innovative policy actions to restore the natural capital [49,50], and

vi. Population Growth: The enormous increase in population growth in many parts of the developed and developing countries is cumbersome to achieving the resource conservation agenda. The population bomb exhausts economic and natural resources in more of the economic development, leading to resource scarcity. The populationcontrolled strategy, human capital formation, and population genius principles can save economic and natural resources for future generations [51].

Based on the stated vital factors, the study formulated the functional relationships between the stated variables, i.e.,

$$
N R D=A\left(F P R N T^{\alpha}, I M S^{\beta}, S Q I M S^{\gamma}, G D P P C^{\delta}, I N D^{\lambda}, P O P G^{\infty}\right)
$$

where, $A$ shows natural resource constant, NRD shows natural resource degradation, EFPRNT, IMS, SQIMS, GDPPC, IND, and POPG shows ecological footprints, international migrant stocks, square of migrant stocks, per capita income, industrial value-added, and population growth.

The log-log transformation is used to obtain the coefficient estimates in elasticities forms, i.e.,

$$
\begin{aligned}
& \ln (N R D)=\ln (A)+\alpha \ln (F P R N T)+\beta \ln (I M S)+\gamma \ln (S Q I M S)+\delta \ln (G D P P C) \\
& +\lambda \ln (I N D)+\omega \ln (P O P G)+\varepsilon
\end{aligned}
$$

where, $\alpha, \beta, \gamma, \delta, \lambda$, and $\omega$ shows output elasticities.

\subsection{Econometric Framework}

The conventional regression apparatus, i.e., 'Ordinary least squares (OLS) estimators', is used in much cross-sectional data series. However, before applying the OLS estimators, it is mainly required to check the presence of any potential outliers in either the regressors, the outcome variable, or both simultaneously. The presence of potential outliers in the given model makes the OLS estimates biased and inconsistent. The robust least squares (RLS) regression gives various regression methods that control outliers in the given model. The three vital RLS estimators are remains used in cross-country data set for estimation, i.e.,

i. Maximum likelihood estimator-like (M-estimator) 
ii. Scale statistic (S-estimator), and

iii. MM-estimator (combination of $\mathrm{S}$ and $\mathrm{M}$ estimator)

M-estimator specifically designed for limiting outliers in the outcome variable. The large value of residuals indicates the presence of outliers in the regression model to address by the Huber [52] estimation procedure. The S-estimator addresses outliers from the predictor variables. The high leverage in the individual regressors makes their estimates biased and inconsistent. Hence, the use of the Rousseeuw and Yohai [53] procedure gives a limit to the regressor's outliers to make the estimates unbiased and efficient. Finally, the MM-estimator was used to address potential outliers in the outcome variable and set of predictor variables by initially performing S-estimation and then linking it to the M-estimation procedure. The Yohai [54] procedure combines both the $S$ and $M$ estimator to address outliers from the studied model. The study used an RLS regression S- estimator based on the influence and leverage plots of the variables. Equation (3) shows the RLS regression S-estimator specifications for ready reference.

$\ln (N R D)_{s}=\ln (A)_{s}+\alpha \ln (F P R N T)_{s}+\beta \ln (I M S)_{s}+\gamma \ln (S Q I M S)_{s}+\delta \ln (G D P P C)_{s}$ $+\lambda \ln (I N D)_{s}+\omega \ln (P O P G)_{s}+\varepsilon_{s}$

where, $\mathrm{S}$ shows the S-estimator of explanatory variables.

Equation (3) shows that ecological footprints are expected to degrade natural resources by overconsumption and overutilization. International migrant stocks increase the size of population growth; thus, both factors are assumed to affect the resource conservation agenda negatively. The hump-shaped relationship is expected between international migrant stocks and natural resource degradation. The continued economic growth and population growth are assumed to affect the resource conservation agenda across countries negatively.

After estimating the RLS regression method, the study evaluated the following causal relationships between the stated variables, i.e.,

i. Natural resource degradation Granger cause of ecological footprints, international migrant stocks, economic growth, industry value-added, and population growth (unidirectional casual relationships)

ii. Ecological footprints, international migrant stocks, economic growth, industry valueadded, and population growth Granger cause natural resource degradation (reverse causality relationships)

iii. Feedback relationships found between the stated variables, and

iv. No causal relationships were found between the variables, although highly correlated.

Finally, the study used variance decomposition analysis to observe the exogenous innovations shocks of the variables over others in the next 10 years' time period. The response variables' innovation shocks also become an essential policy implication for understanding its predictions to move with the set of exogenous variables. The explanatory factors would likely show their innovation shocks over a while.

\section{Results}

Table 3 shows the descriptive statistics of the studied variables. The maximum value of natural resource degradation is $37.105 \%$ of GNI with an average value of $3.106 \%$ with a standard deviation value of $5.771 \%$. Ecological footprints increase along with international migrant stocks and industrial value-added with an average value of 9,403,143 arable lands in hectares, $7.522 \%$ of the population, and $27.152 \%$ of GDP. The minimum value of per capita income among the cross-sections is US\$208.074, and the maximum value is US\$92123.710, with an average value of US\$12622.070. The maximum value of the population is $4.468 \%$ annual, with an average rate of $1.484 \%$. The trend values of the respective variables suggested the cross-sectional profiles of the countries' variables that are important for subsequent estimations. 
Table 3. Descriptive Statistics.

\begin{tabular}{ccccccc}
\hline Methods & NRD & EFPRNT & IMS & GDPPC & IND & POPG \\
\hline Mean & 3.106 & $9,403,143$ & 7.522 & $12,622.070$ & 27.152 & 1.484 \\
\hline Maximum & 37.105 & $1.58 \times 10^{8}$ & 88.404 & $92,123.710$ & 62.515 & 4.468 \\
\hline Minimum & 0.00014 & 150 & 0.071 & 208.074 & 5.237 & 0.023 \\
\hline Std. Dev. & 5.771 & $24,349,212$ & 12.525 & $17,756.290$ & 10.304 & 0.998 \\
\hline Skewness & 3.362 & 4.734 & 3.843 & 2.150 & 0.890 & 0.445 \\
\hline Kurtosis & 15.921 & 26.441 & 21.310 & 7.434 & 4.030 & 2.354 \\
\hline
\end{tabular}

Note: NRD shows natural resource depletion, EFPRINT shows ecological footprints, IMS shows international migrant stock, GDPPC shows GDP per capita, IND shows industry value-added, and POPG shows population growth.

Table 4 shows the correlation estimates. Industry value-added and population growth are the significant contributors that degrade natural resources with correlation coefficient values of $\mathrm{r}=0.567 p<0.000$ and $\mathrm{r}=0.358 p<0.000$, respectively. The high industrialization and continued economic growth are the chief factors of international migrating refugees from one country to another. The estimates confirmed the positive correlation between economic growth and international migrant stocks with a correlation coefficient value of $\mathrm{r}=0.498 p<0.000$ and industrialization and international refugee stock with $\mathrm{r}=0.287$ $p<0.000$. Population growth decreases economic growth and increases resource degradation with correlation coefficient values of $\mathrm{r}=-0.385 p<0.000$ and $\mathrm{r}=0.358 p<0.000$, respectively, across countries.

Table 4. Correlation Matrix.

\begin{tabular}{|c|c|c|c|c|c|c|}
\hline \multicolumn{2}{|c|}{ Correlation } & \multirow[b]{2}{*}{ EFPNT } & \multirow[b]{2}{*}{ IMS } & \multirow[b]{2}{*}{ GDPPC } & \multirow[b]{2}{*}{ IND } & \multirow[b]{2}{*}{ POPG } \\
\hline Probability & NRD & & & & & \\
\hline \multirow[t]{2}{*}{ NRD } & 1 & & & & & \\
\hline & $\overline{-}$ & & & & & \\
\hline \multirow[t]{2}{*}{ EFPRNT } & -0.052 & 1 & & & & \\
\hline & $(0.541)$ & - & & & & \\
\hline \multirow[t]{2}{*}{ IMS } & 0.119 & -0.060 & 1 & & & \\
\hline & $(0.161)$ & $(0.483)$ & - & & & \\
\hline \multirow[t]{2}{*}{ GDPPC } & -0.091 & 0.059 & 0.498 & 1 & & \\
\hline & $(0.285)$ & $(0.485)$ & $(0.000)$ & - & & \\
\hline \multirow[t]{2}{*}{ IND } & 0.567 & -0.018 & 0.287 & 0.073 & 1 & \\
\hline & $(0.000)$ & $(0.830)$ & $(0.000)$ & $(0.390)$ & - & \\
\hline \multirow[t]{2}{*}{ POPG } & 0.358 & -0.160 & 0.013 & -0.385 & 0.076 & 1 \\
\hline & $(0.000)$ & $(0.060)$ & $(0.876)$ & $(0.000)$ & $(0.374)$ & - \\
\hline
\end{tabular}

Note: NRD shows natural resource depletion, EFPRINT shows ecological footprints, IMS shows international migrant stock, GDPPC shows GDP per capita, IND shows industry value-added, and POPG shows population growth. Small bracket shows probability value.

After analyzing the correlation relationships between the candidate variables, the study proceeds to analyze pre-requisite tests using the appropriate regression apparatus. Figure 1 shows the influencing statistics of the models for identifying the possible outliers in the given model. 
RStudent

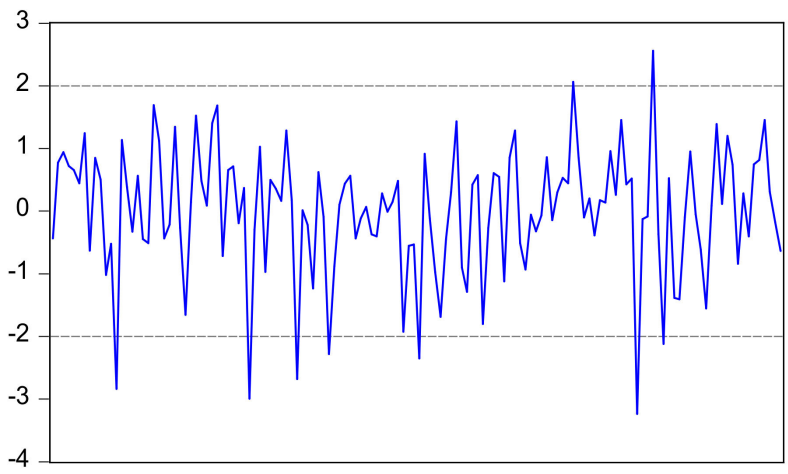

Cross-Sectional Data Set of 138 Countries
Hat Matrix

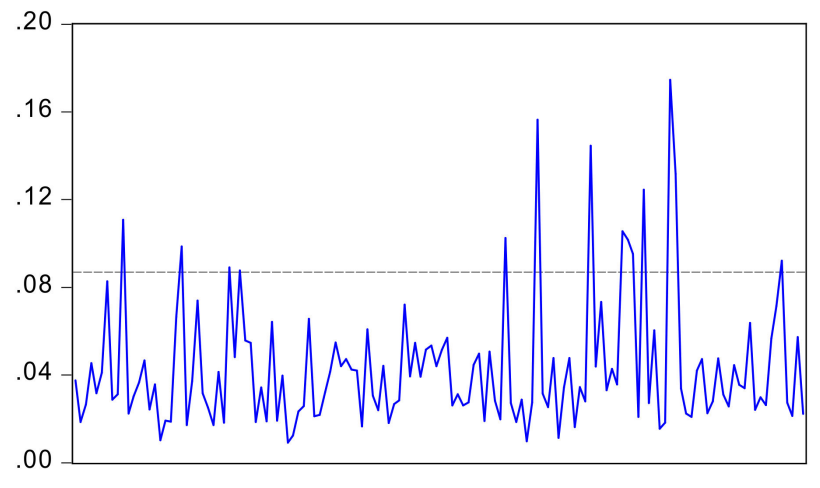

Cross-Sectional Data Set of 138 Countries
DFFITS

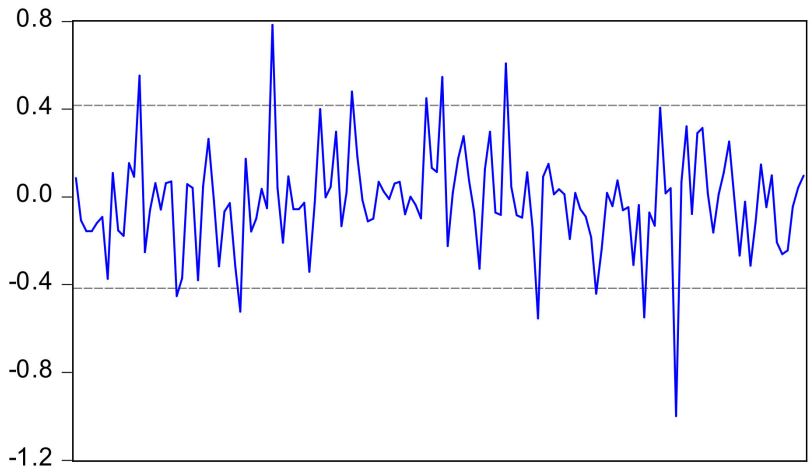

Cross-Sectional Data Set of 138 Countries
COVRATIO

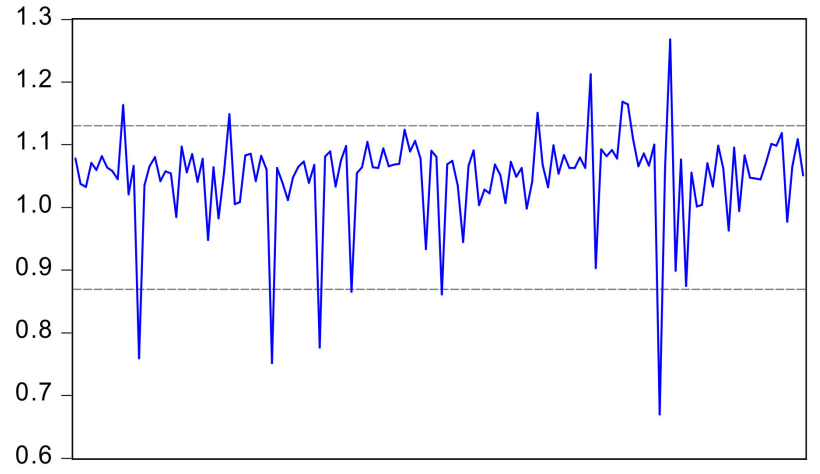

Cross-Sectional Data Set of 138 Countries

Figure 1. Influence Statistics. Source: Authors Estimation.

Figure 1 illustrates the four different influencing statistics, i.e., R-student, Hat Matrix, DFFITS, and COVRATIO, to detect the possible outliers in the cross-section of 138 countries. The R-student statistics confirmed eight outliers that exceed the average value line. The Hat Matrix detects 10 possible outliers; DFFITS and COVRATIO show seven possible outliers in the given model. Hence, it is vital to identify the given outliers that mainly exists in the 'response variable', or in the 'regressors' or exists outliers on both sides. Figure 2 shows the leverage plots of each variable to identify the place of existence of possible outliers among the variables. 


\section{LNNRD vs Variables (Partialled on Regressors)}
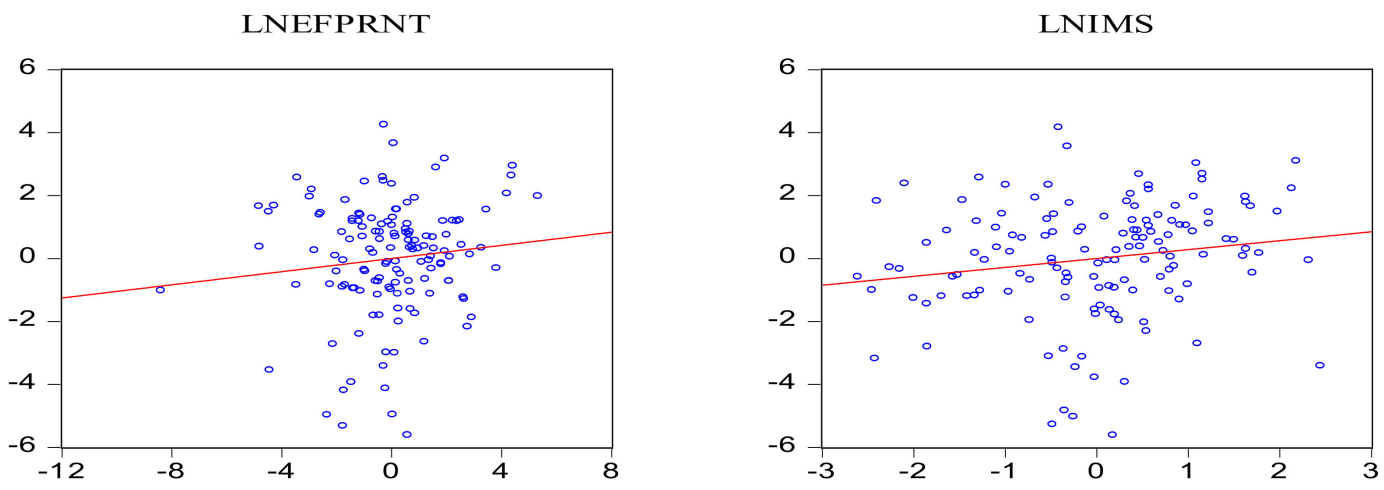

LNGDPPC
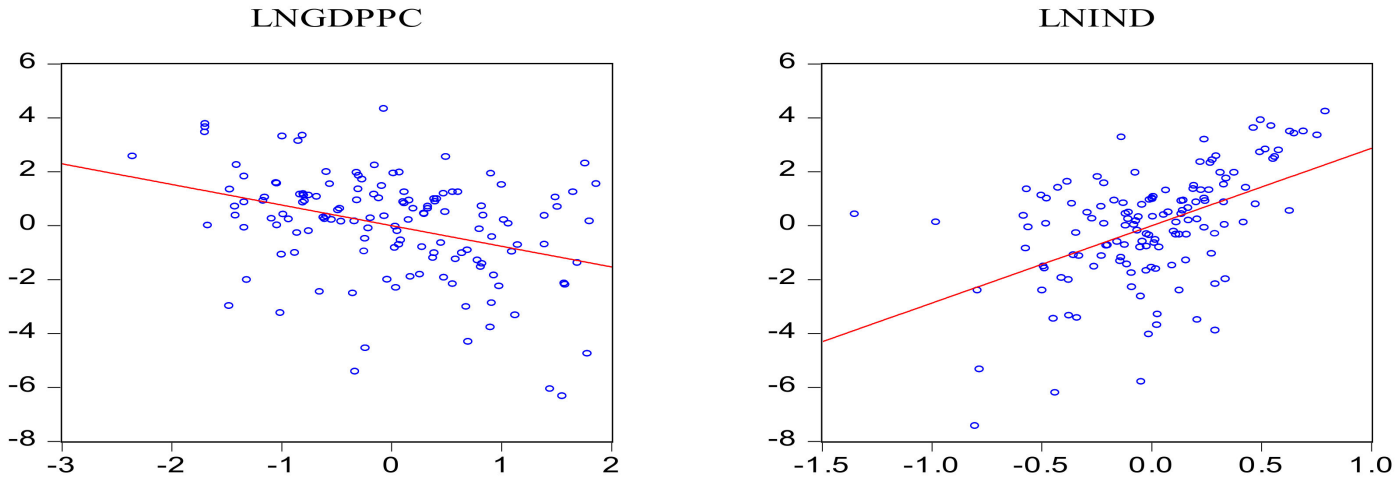

LNPOPG

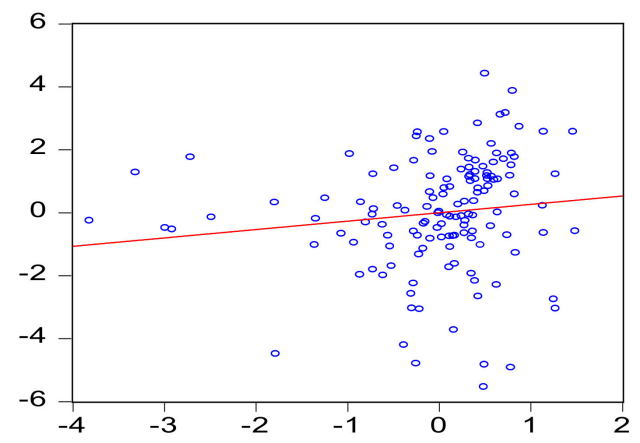

Figure 2. Leverage Plots. Source: Authors Estimation. Note: NRD shows natural resource depletion, EFPRINT shows ecological footprints, IMS shows international migrant stock, GDPPC shows GDP per capita, IND shows industry valueadded, and POPG shows population growth.

Figure 2 illustrates that the variables plots are highly dispersed around the expected value of the response variable. Hence, it is evident that the possible outliers mainly fall in the regressors. Hence, the study used a cross-sectional robust least squares (RLS) regression S-estimator to address the outliers from the given system. Before going to estimate RLS estimator, the study performs cross-sectional unit root test and cointegration test. Tables 5 and 6 shows both the test for ready reference. 
Table 5. Cross-Sectional Unit Root Test Estimates.

\begin{tabular}{ccccc}
\hline \multirow{2}{*}{ Variables } & \multicolumn{2}{c}{ Level } & \multicolumn{2}{c}{ First Difference } \\
\cline { 2 - 5 } & Constant & Constant and Trend & Constant & Constant and Trend \\
\hline \multirow{2}{*}{$\ln ($ EFPRNT) } & -13.284 & -13.305 & -10.583 & -10.593 \\
& $(0.000)$ & $(0.000)$ & $(0.000)$ & $(0.000)$ \\
\hline \multirow{2}{*}{$\ln (\mathrm{IMS})$} & -9.057 & -9.025 & -10.634 & -10.621 \\
& $(0.000)$ & $(0.000)$ & $(0.000)$ & $(0.000)$ \\
\hline \multirow{2}{*}{$\ln (\mathrm{GDPPC})$} & -10.045 & -10.005 & -9.865 & -9.828 \\
& $(0.000)$ & $(0.000)$ & $(0.000)$ & $(0.000)$ \\
\hline \multirow{2}{*}{$\ln (\mathrm{IND})$} & -11.908 & -11.864 & -10.111 & -10.078 \\
& $(0.000)$ & $(0.000)$ & $(0.000)$ & $(0.000)$ \\
\hline \multirow{2}{*}{$\ln (\mathrm{POPG})$} & -11.517 & -11.552 & -8.764 & -8.726 \\
& $(0.000)$ & $(0.000)$ & $(0.000)$ & $(0.000)$ \\
\hline
\end{tabular}

Note: ' $I n$ ' shows natural logarithm. Small bracket shows probability value. NRD shows natural resource depletion, EFPRINT shows ecological footprints, IMS shows international migrant stock, GDPPC shows GDP per capita, IND shows industry value-added, and POPG shows population growth.

Table 6. Cross-Sectional Cointegration Estimates.

\begin{tabular}{|c|c|c|c|c|}
\hline \multicolumn{5}{|c|}{ Unrestricted Cointegration Rank Test (Trace) } \\
\hline Hypothesized & & Trace & 0.05 & \\
\hline No. of CE(s) & Eigenvalue & Statistic & Critical Value & Prob. * \\
\hline None * & 0.362026 & 216.0534 & 95.75366 & 0.0000 \\
\hline At most 1 * & 0.261287 & 156.2754 & 69.81889 & 0.0000 \\
\hline At most $2 *$ & 0.231107 & 115.9969 & 47.85613 & 0.0000 \\
\hline At most $3 *$ & 0.215817 & 81.04412 & 29.79707 & 0.0000 \\
\hline At most $4 *$ & 0.191576 & 48.71018 & 15.49471 & 0.0000 \\
\hline At most $5 *$ & 0.142362 & 20.42524 & 3.841466 & 0.0000 \\
\hline
\end{tabular}

Note: * indicates $1 \%$ significance level.

The results show that the candidate variables are level stationary, hence, the variable's order of integration is zero, i.e., I(0) variables. The cross-sectional unit root estimates give a good rationale to used RLS estimator, however, before, proceeding towards it, the study estimate cross-sectional cointegration test. Table 6 shows the cointegration test and confirmed that the model has a six cointegrating equations, which confirmed the long-run relationship between the variables.

After confirmation of long-run relationships between the variables, Table 7 shows the estimates of RLS regression by S-estimator.

The results show a positive relationship (negative impact) between ecological footprints and natural resource degradation across countries. The result implies that a $1 \%$ increase in ecological footprints reduces natural resource assets by $0.108 \%$. The enormous increase in human activities on arable land put more pressure on economic and natural resources to bring down resource capital for future generations. The result is backed by the industrial value-added and natural resource degradation estimates verifying the more elastic relationships between the two stated variables. The elasticity estimates show that a $1 \%$ increase in industrial value-added reduces natural resource assets by $3.431 \%$, which shows greater pressure on arable land due to unsustainable economic activities. The increase in international migrant stocks increases population growth. It puts pressure on arable land to overuse economic and natural resources, bringing down the resource conservation agenda across countries. The hump-shaped relationship was found between international migrant stocks and natural resource degradation in a given period. The increase in international migration tends to increase resource degradation initially by the elasticity estimates of $0.441 \%$. In comparison, it conserves natural resources at the later stages of economic development with an estimate of $-0.081 \%$. Thus, it shows an inverted U-shaped relationship between them. The continued economic growth supports the resource conservation agenda, which 
indicates the recovery in the global economic policies to restore natural capital through sound regulations.

Table 7. Robust Least Squares Regression by S- Estimator.

\begin{tabular}{|c|c|c|c|c|}
\hline \multicolumn{5}{|c|}{ Dependent Variable: $\ln (\mathrm{NRD})$} \\
\hline Variable & Coefficient & Std. Error & z-Statistic & Prob. \\
\hline $\ln ($ EFPRNT $)$ & 0.108277 & 0.057904 & 1.869940 & 0.0615 \\
\hline $\ln (\mathrm{IMS})$ & 0.441099 & 0.121677 & 3.625156 & 0.0003 \\
\hline $\ln (\mathrm{IMS}) \wedge 2$ & -0.081511 & 0.046977 & -1.735127 & 0.0827 \\
\hline $\ln (\mathrm{GDPPC})$ & -0.248467 & 0.133109 & -1.866635 & 0.0620 \\
\hline $\ln (\mathrm{IND})$ & 3.433646 & 0.324012 & 10.59728 & 0.0000 \\
\hline $\ln (\mathrm{POPG})$ & 0.491687 & 0.132943 & 3.698489 & 0.0002 \\
\hline Constant & -10.65524 & 1.453829 & -7.329087 & 0.0000 \\
\hline \multicolumn{5}{|c|}{ Robust Statistics } \\
\hline R-squared & 0.370038 & \multicolumn{2}{|c|}{ Adjusted R-squared } & 0.341185 \\
\hline Scale & 1.362840 & \multicolumn{2}{|c|}{ Deviance } & 1.857334 \\
\hline Rn-squared statistic & 155.5959 & \multicolumn{2}{|c|}{ Prob(Rn-squared stat.) } & 0.000000 \\
\hline \multicolumn{5}{|c|}{ Non-robust Statistics } \\
\hline Mean dependent var & -0.458780 & \multicolumn{2}{|c|}{ S.D. dependent var } & 2.278352 \\
\hline S.E. of regression & 2.031650 & \multicolumn{2}{|c|}{ Sum squared resid } & 540.7157 \\
\hline \multicolumn{5}{|c|}{ Diagnostic Tests } \\
\hline \multicolumn{5}{|c|}{ Autocorrelation-LM(2) Test: 2.250 [0.109] } \\
\hline \multicolumn{5}{|c|}{ Heteroskedasticity Test:1.221 [0.234] } \\
\hline \multicolumn{5}{|c|}{ Ramsey RESET Test: 0.055 [0.956] } \\
\hline
\end{tabular}

Note: NRD shows natural resource depletion, EFPRINT shows ecological footprints, IMS shows international migrant stock, GDPPC shows GDP per capita, IND shows industry value-added, and POPG shows population growth.

\section{Discussion}

The results are in line with the earlier studies backed by resource conservation policies. For instance, Nassani et al. [19] argued that an increasing ecological footprint hampers resource conservation agenda to overuse resource extractions. The need to attain energy efficiency in extractive industries is helpful to mitigate adverse environmental externalities backed up by the green financing instruments and provision of insurance services. Naseer et al. [55] concluded that resource financing, investment inflows, technological upgradation, and natural resource mobilization help restore economic beauty by conserving natural resources for future generations. Christoforidis and Katrakilidis [56] highlighted the need to improve institutional quality for managing natural resource assets by amalgamating renewable energy sources in resourceful agenda. Anser et al. [57] found that carbon pricing and knowledge spillovers are the crucial factors to reduce adverse environmental externalities, which need further assessment to indulge financing instruments and technological factors in supporting natural resource capital. Danish et al. [18] concluded that adopting green energy sources in conventional energy sources and increase resource rents helpful to restore the beauty of natural resources by reducing ecological footprints. Khan et al. [58] argued that optimum utilization of natural resources and green energy sources is helpful to improve environmental quality. In comparison, the increased use of non-renewable energy sources in economic production and an enormous increase in population growth hampers the environmental sustainability agenda. Abbas et al. [59] criticized unsustainable foreign investment that leads to validate pollution haven hypothesis and irresponsible production and consumption, causing greater environmental resource degradation. The study stressed the need to improve the commodity market by attracting foreign investors to invest in cleaner technologies, which help improve resource quality. Maja and Ayano [60] found that rapid population growth hampers economic activities, deteriorating environmental quality and threat to overuse of natural resources. The intensive farming practices, overutilization of natural resources, and land destruction are some causal factors of deteriorating resource quality. The need to adopt climate mitigation strategies help to 
save natural resource capital globally. Table 8 shows the cross-sectional causality estimates for ready reference.

Table 8. Cross-Sectional Granger Causality Estimates.

\begin{tabular}{cc}
\hline Causal Directions & Policy Remarks \\
\hline $\ln (\mathrm{IMS}) \rightarrow \ln (\mathrm{NRD})$ & International migrant stock -led natural resource depletion \\
\hline $\ln (\mathrm{GDPPC}) \rightarrow \ln (\mathrm{NRD})$ & Economic growth -led natural resource depletion \\
\hline $\ln (\mathrm{POPG}) \rightarrow \ln (\mathrm{NRD})$ & Population growth -led natural resource depletion \\
\hline $\ln (\mathrm{EFPRNT}) \rightarrow \ln (\mathrm{IND})$ & $\begin{array}{c}\text { Ecological footprint caused by high industrial } \\
\text { value-added }\end{array}$ \\
\hline
\end{tabular}

Note: NRD shows natural resource depletion, EFPRINT shows ecological footprints, IMS shows international migrant stock, GDPPC shows GDP per capita, IND shows industry value-added, and POPG shows population growth.

The causality estimates confirmed the unidirectional linkages between the variables to authenticate different economic situations. The international migrant stocks Granger cause natural resource degradation confirmed the migration-led resource degradation across countries. The greater the international stocks of refugees put more pressure on land-use changes that deteriorates the resource conservation agenda. Further, continued economic growth Granger cause resource degradation indicates that for maintaining a rapid pace of economic growth, the countries need to overuse their natural resources to meet the challenges of globalization. Population growth Granger cause natural resource degradation to nullify the population genius principle and emphasize the need for human capital transformation to reduce resource destruction across countries. Finally, ecological footprints Granger cause industrialization, affirming human pressure on arable land deteriorating more natural resources via a channel of an increased industrialization process. Table 9 shows the VDA estimates of natural resource degradation.

Table 9. VDA of $\ln (\mathrm{NRD})$.

\begin{tabular}{cccccccc}
\hline Period & S.E. & $\ln ($ NRD) & $\ln ($ EFPRNT) & $\ln ($ IMS) & $\ln ($ GDPPC) & $\ln ($ IND) & $\ln ($ POPG) \\
\hline 2022 & 2.225344 & 100 & 0 & 0 & 0 & 0 & 0 \\
2023 & 2.315782 & 92.58730 & 0.752444 & 4.904185 & 1.118411 & $9.78 \times 10^{-5}$ & 0.637558 \\
2024 & 2.394538 & 87.27020 & 1.234873 & 4.592637 & 4.771751 & 0.346045 & 1.784489 \\
2025 & 2.399960 & 86.93977 & 1.233549 & 4.632937 & 4.793728 & 0.613261 & 1.786753 \\
2026 & 2.402415 & 86.79027 & 1.231246 & 4.690580 & 4.794914 & 0.665471 & 1.827523 \\
2027 & 2.403326 & 86.73962 & 1.245625 & 4.709575 & 4.791607 & 0.684321 & 1.829256 \\
2028 & 2.403476 & 86.72928 & 1.245501 & 4.709112 & 4.791795 & 0.694360 & 1.829956 \\
2029 & 2.403621 & 86.72331 & 1.247246 & 4.708880 & 4.791502 & 0.699291 & 1.829774 \\
2030 & 2.403638 & 86.72228 & 1.247275 & 4.709508 & 4.791453 & 0.699713 & 1.829772 \\
2031 & 2.403655 & 86.72174 & 1.247501 & 4.709560 & 4.791420 & 0.700020 & 1.829762 \\
\hline
\end{tabular}

Note: NRD shows natural resource depletion, EFPRINT shows ecological footprints, IMS shows international migrant stock, GDPPC shows GDP per capita, IND shows industry value-added, and POPG shows population growth.

The results suggest that continued economic growth would likely obstruct the pace of the resource conservation agenda, as its innovation shocks are greater than other studied factors on the natural resource degradation for the next 10 years' time period. The per capita income would likely influence resource markets by its innovation shock of $4.791 \%$ in 2031. The second influencing factor of resource degradation would likely be an increase in migrant stocks with a variance shock of $4.709 \%$ in 2031 . The rapid population growth and ecological footprints exhibit variance shocks of $1.829 \%$ and $1.247 \%$, respectively. Finally, industrial value-added would likely influence natural resource capital by $0.700 \%$ over a time horizon. Thus, the study safely concludes that the stated variables would likely influence the resource conservation agenda in the subsequent years. 


\section{Conclusions}

The enormous increase in ecological footprints obstructs the green developmental process. International migrant stocks deteriorating physical capacity indicators that hampers resource sustainability agenda. The increase in industrial production accommodates the immense population growth on the cost of natural resource degradation. Based on the stated issues, the study explored the relationship between ecological footprints, international migrant stocks, economic growth, industrialization, population growth, and their impact on natural resource degradation across countries. The results show that ecologic footprints increase natural resource degradation via industrial production and population growth. On the other hand, continued economic growth decreases resource degradation and is helpful to attaining green developmental agenda. The hump-shaped relationship was found between international migrant stocks and natural resource degradation. In the first instance, the increase in international migrant stocks increases resource degradation, while at a later stage, it decreases resource degradation to support resource sustainability agenda across countries. The casual inferences show the unidirectional relationships between (i) international migrant stocks to natural resource degradation, (ii) economic growth to resource degradation, (iii) population growth to resource degradation, and (iv) ecological footprints to industrialization. The stated casual relationships confirmed the migrants-led, economic growth-led, population-led resource degradation, and ecological footprints-led industrialization. The VDA analysis suggested that economic growth and international migrant stocks would likely play the crucial role of having more than $4 \%$ of their innovation shocks on natural resource degradation for the next 10 years. Further, population growth and ecological footprints having more than $1.8 \%$ and $1.2 \%$ innovation shocks on resource degradation. Industrialization would be likely to have the least influence on resource degradation over a time horizon. Based on the findings, the following three-point agenda is suggested to the policymakers for efficiently managing the natural resource capital globally, i.e.,

i. The growing pressure of humans on arable land, deteriorating natural resources. The rise in deforestation, exhausting mineral resources during the extraction process, depleting energy and oil resources, and coal combustions negatively affect the environment and healthcare sustainability agenda, which need to be settled through efficient resource policies. The following sub-policies need to be applied for conserving natural resources, i.e.,

- The lowering down deforestation level to save natural habitats.

- Improve technological expertise for resource extraction without losing mineral resources.

- Conserving energy and oil resources for future generations, and

- Avoid coal combustions and switch over to renewable fuels.

The rise in ecological footprints is cumbersome to the United Nations' resource sustainability agenda. The need to be overcome through national and regional cooperation, technology transfers, and stringent resource regulations.

ii The rise in international migrant stocks in many parts of the globalized world threatened the resource commodity market. Natural resources are overused in industrial production to meet the needs of domestic and international demand. It is imperative to make intelligent decisions to relocate international refugees to appropriate places and indulge in the economic process to improve economic efficiency. The following sub-policies are suggested for managing stocks of international refugees to efficiently use natural resources, i.e.,

- The countries need to increase their net national welfare index to support international refugees and conserve natural resources.

- Improving inclusive wealth indicators to support efficiency parameters, and

- Expanding safety standards for international refugees and sustainable harvesting the renewable resources to acquire maximum sustainable yields. 
The countries need to adopt normative standards for managing natural resources, which would be helpful to increase the net national welfare and inclusive wealth indicators to avoid health risks.

iii Responsible production and consumption remain to have a place in the commodity resource market to improve industrial standards that absorb the massive population growth to fulfil their demands at the domestic and international level. The ecological sustainability standards should be adopted that helps to protect natural ecosystems. The following sub-policies are helpful to achieve the stated goals, i.e.,

- The command-and-control system should be efficient.

- Technological-based regulations help to reduce the overconsumption of natural resources in industrial production.

- Incentive-based regulations help to avoid resource wastes, and

- National and international collaborations would be helpful to avoid dirty production.

The Pareto-efficient situation can be possible to achieve whenever the natural resources would be managed efficiently. The regulator impacts analysis may help sustain industrial production and resource consumption by managing international refugees' stocks worldwide.

Author Contributions: Conceptualization, T.-C.L. and M.K.A.; methodology, T.-C.L.; software, K.Z.; validation, A.A.N., M.H. and M.M.Q.A.; formal analysis, T.-C.L., M.K.A., A.A.N., M.H., K.Z. and M.M.Q.A.; investigation, T.-C.L.; resources, M.K.A.; data curation, M.H.; writing—original draft preparation, T.-C.L., M.K.A., A.A.N. and M.H.; writing-review and editing, T.-C.L., M.K.A., A.A.N., M.H., K.Z. and M.M.Q.A.; visualization, T.-C.L.; supervision, T.-C.L., M.K.A. and A.A.N.; project administration, T.-C.L., M.K.A. and A.A.N.; funding acquisition, A.A.N. and T.-C.L. All authors have read and agreed to the published version of the manuscript.

Funding: Researchers Supporting Project number (RSP-2021/87), King Saud University, Riyadh, Saudi Arabia.

Institutional Review Board Statement: Not applicable.

Informed Consent Statement: Not applicable.

Data Availability Statement: The data is freely available at World Development Indicators published by World Bank (2021) at https: / / databank.worldbank.org/source/world-development-indicators, accessed on 12 June 2021).

Acknowledgments: Researchers Supporting Project number (RSP-2021/87), King Saud University, Riyadh, Saudi Arabia.

Conflicts of Interest: The authors declare no conflict of interest.

\section{Appendix A}

Table A1. List of Sample Countries.

\begin{tabular}{l}
\hline Afghanistan, Albania, Algeria, Angola, Argentina, Armenia, Australia, Austria, Azerbaijan \\
\hline Bahrain, Bangladesh, Belarus, Belgium, Belize, Benin, Bhutan, Bolivia, Bosnia and Herzegovina, \\
Botswana, Brazil, Brunei Darussalam, Bulgaria, Burkina Faso, Burundi \\
\hline Cabo Verde, Cambodia, Cameroon, Chad, Chile, China, Colombia, Comoros, Congo Dem. Rep. \\
Congo Rep., Costa Rica, Cote d'Ivoire, Croatia, Cyprus, Czech Republic \\
\hline Denmark, Dominican Republic \\
\hline Ecuador, Egypt, El Salvador, Equatorial, Guinea, Estonia, Eswatini, Ethiopia \\
\hline Finland, France \\
\hline Gabon, Gambia, Georgia, Germany, Ghana, Greece, Guatemala, Guinea, Guinea-Bissau, Guyana \\
\hline
\end{tabular}


Table A1. Cont.

\begin{tabular}{l}
\hline Haiti, Honduras, Hungary \\
\hline India, Indonesia, Iraq, Ireland, Israel, Italy \\
\hline Jordan \\
\hline Kazakhstan, Kenya, Korea Rep., Kyrgyz Republic \\
\hline Lao PDR, Lesotho, Liberia, Lithuania \\
\hline Madagascar, Malawi, Malaysia, Maldives, Mali, Mauritania, Mexico, Moldova, Mongolia, \\
Montenegro, Morocco, Mozambique, Myanmar \\
\hline Namibia, Nepal, Netherlands, Nicaragua, Niger, Nigeria, North Macedonia, Norway \\
\hline Oman \\
\hline Pakistan, Peru, Philippines, Poland, Portugal \\
\hline Qatar \\
\hline Romania, Russian Federation, Rwanda \\
\hline Saudi Arabia, Senegal, Serbia, Seychelles, Sierra Leone, Slovak Republic, Slovenia, South Africa, \\
Spain, Sri Lanka, Sudan, Suriname, Sweden \\
\hline Tajikistan, Tanzania, Thailand, Timor-Leste, Togo, Trinidad and Tobago, Tunisia, Turkey \\
\hline Uganda, Ukraine, United Arab Emirates, United States, Uruguay, Uzbekistan \\
\hline Vietnam \\
\hline Zambia \\
\hline
\end{tabular}

\section{References}

1. Khan, N.H.; Ju, Y.; Latif, Z.; Khan, K. Nexus between carbon emission, financial development, and access to electricity: Incorporating the role of natural resources and population growth. J. Public. Aff. 2021, 21, e2131. [CrossRef]

2. Akhter, W.; Zaman, K.; Nassani, A.A.; Abro, M.M.Q. Nexus between natural and technical disaster shocks, resource depletion and growth-specific factors: Evidence from quantile regression. Nat. Hazards 2020, 104, 143-169. [CrossRef]

3. Chevallier, J.; Goutte, S.; Ji, Q.; Guesmi, K. Green finance and the restructuring of the oil-gas-coal business model under carbon asset stranding constraints. Energy Policy 2021, 149, 112055. [CrossRef]

4. Ullah, S.; Gang, T.; Rauf, T.; Sikandar, F.; Liu, J.Q.; Noor, R.S. Identifying the socio-economic factors of deforestation and degradation: A case study in Gilgit Baltistan, Pakistan. GeoJournal 2020, 1-14. [CrossRef]

5. World Bank. World Development Indicators; World Bank: Washington, DC, USA, 2021.

6. Duro, J.A.; Piccione, V.; Ragusa, M.A.; Veneziano, V. New Enviromentally Sensitive Patch Index-ESPI-for MEDALUS protocol. AIP Conf. Proc. 2014, 1637, 305-312.

7. Hefty, K.L.; Koprowski, J.L. Multiscale effects of habitat loss and degradation on occurrence and landscape connectivity of a threatened subspecies. Conserv. Sci. Pract. 2021, e547. [CrossRef]

8. Nathaniel, S.P.; Nwulu, N.; Bekun, F. Natural resource, globalization, urbanization, human capital, and environmental degradation in Latin American and Caribbean countries. Environ. Sci. Pollut. Res. 2021, 28, 6207-6221. [CrossRef]

9. Anser, M.K.; Nassani, A.A.; Zaman, K.; Abro, M.M.Q. Environmental and natural resource degradation in the wake of COVID-19 pandemic: A wake-up call. Environ. Sci. Pollut. Res. 2021, 1-11. [CrossRef]

10. Muhammad, B.; Khan, M.K.; Khan, M.I.; Khan, S. Impact of foreign direct investment, natural resources, renewable energy consumption, and economic growth on environmental degradation: Evidence from BRICS, developing, developed and global countries. Environ. Sci. Pollut. Res. 2021, 28, 21789-21798.

11. Bergius, M.; Benjaminsen, T.A.; Maganga, F.; Buhaug, H. Green economy, degradation narratives, and land-use conflicts in Tanzania. World Dev. 2020, 129, 104850. [CrossRef]

12. Ahmed, Z.; Asghar, M.M.; Malik, M.N.; Nawaz, K. Moving towards a sustainable environment: The dynamic linkage between natural resources, human capital, urbanization, economic growth, and ecological footprint in China. Resour. Policy 2020, 67, 101677. [CrossRef]

13. Nguyen, T.T.; Do, T.L.; Halkos, G.; Wilson, C. Health shocks and natural resource extraction: A Cambodian case study. Ecol. Econ. 2020, 169, 106517. [CrossRef]

14. Younis, I.; Naz, A.; Shah, S.A.A.; Nadeem, M.; Longsheng, C. Impact of stock market, renewable energy consumption and urbanization on environmental degradation: New evidence from BRICS countries. Environ. Sci. Pollut. Res. 2021, 28, 31549-31565. [CrossRef] 
15. Khan, I.; Hou, F.; Le, H.P. The impact of natural resources, energy consumption, and population growth on environmental quality: Fresh evidence from the United States of America. Sci. Total Environ. 2021, 754, 142222. [CrossRef] [PubMed]

16. Majeed, A.; Wang, L.; Zhang, X.; Kirikkaleli, D. Modeling the dynamic links among natural resources, economic globalization, disaggregated energy consumption, and environmental quality: Fresh evidence from GCC economies. Resour. Policy 2021, 73, 102204. [CrossRef]

17. Umar, M.; Ji, X.; Kirikkaleli, D.; Shahbaz, M.; Zhou, X. Environmental cost of natural resources utilization and economic growth: Can China shift some burden through globalization for sustainable development? Sustain. Dev. 2020, 28, 1678-1688. [CrossRef]

18. Danish, U.R.; Khan, S.U.D. Determinants of the ecological footprint: Role of renewable energy, natural resources, and urbanization. Sustain. Cities Soc. 2020, 54, 101996. [CrossRef]

19. Nassani, A.A.; Aldakhil, A.M.; Zaman, K. Ecological footprints jeopardy for mineral resource extraction: Efficient use of energy, financial development and insurance services to conserve natural resources. Resour. Policy 2021, 74, 102271. [CrossRef]

20. Sun, X.; Chenggang, Y.; Khan, A.; Hussain, J.; Bano, S. The role of tourism, and natural resources in the energy-pollution-growth nexus: An analysis of belt and road initiative countries. J. Environ. Plan. Manag. 2021, 64, 999-1020. [CrossRef]

21. Zaman, K.; Aziz, A.R.A.; Sriyanto, S.; Indrianti, Y.; Jambari, H. The role of solar energy demand in the relationship between carbon pricing and environmental degradation: A blessing in disguise. J. Public Aff. 2021, e2702. [CrossRef]

22. Gyamfi, B.A.; Ozturk, I.; Bein, M.A.; Bekun, F.V. An investigation into the anthropogenic effect of biomass energy utilization and economic sustainability on environmental degradation in E7 economies. Biofuels Bioprod. Biorefin. 2021, 15, 840-851. [CrossRef]

23. Du, C.; Anser, M.K.; Peng, M.Y.P.; Askar, S.E.; Nassani, A.A.; Zaman, K.; Abro, M.M.Q. Women's autonomy and its impact on environmental sustainability agenda. J. Environ. Plan. Manag. 2021, 1-21. [CrossRef]

24. Rehman, A.; Ma, H.; Ozturk, I.; Ahmad, M.I. Examining the carbon emissions and climate impacts on main agricultural crops production and land use: Updated evidence from Pakistan. Environ. Sci. Pollut. Res. 2021, 1-15. [CrossRef]

25. Anser, M.K.; Ahmad, M.; Khan, M.A.; Nassani, A.A.; Askar, S.E.; Zaman, K.; Qazi Abro, M.M.; Kabbani, A. Progress in nuclear energy with carbon pricing to achieve environmental sustainability agenda: On the edge of one's seat. Environ. Sci. Pollut. Res. 2021, 28, 34328-34343. [CrossRef]

26. Usman, A.; Ozturk, I.; Ullah, S.; Hassan, A. Does ICT have symmetric or asymmetric effects on CO2 emissions? Evidence from selected Asian economies. Technol. Soc. 2021, 67, 101692. [CrossRef]

27. Imran, M.; Khan, K.B.; Zaman, K.; Musah, M.B.; Sudiapermana, E.; Aziz, A.R.A.; Embong, R.; Hassan, Z.B.; Jabor, M.M.; Anis, S.N.M. Achieving pro-poor growth and environmental sustainability agenda through information technologies: As right as rain. Environ. Sci. Pollut. Res. 2021, 28, 41000-41015. [CrossRef]

28. Sharma, R.; Shahbaz, M.; Kautish, P.; Vo, X.V. Does energy consumption reinforce environmental pollution? Evidence from emerging Asian economies. J. Environ. Manag. 2021, 297, 113272. [CrossRef]

29. Cheng, Y.; Awan, U.; Ahmad, S.; Tan, Z. How do technological innovation and fiscal decentralization affect the environment? A story of the fourth industrial revolution and sustainable growth. Technol. Forecast. Soc. Chang. 2021, 162, 120398. [CrossRef]

30. Zeraibi, A.; Balsalobre-Lorente, D.; Murshed, M. The influences of renewable electricity generation, technological innovation, financial development, and economic growth on ecological footprints in ASEAN-5 countries. Environ. Sci. Pollut. Res. 2021, 28, 51003-51021. [CrossRef] [PubMed]

31. Yilanci, V.; Ulucak, R.; Ozgur, O. Insights for a sustainable environment: Analysing the persistence of policy shocks to ecological footprints of Mediterranean countries. Spat. Econ. Anal. 2021, 1-20. [CrossRef]

32. Zia, S.; ur Rahman, M.; Noor, M.H.; Khan, M.K.; Bibi, M.; Godil, D.I.; Quddoos, M.U.; Anser, M.K. Striving towards environmental sustainability: How natural resources, human capital, financial development, and economic growth interact with ecological footprint in China. Environ. Sci. Pollut. Res. 2021, 28, 52499-52513. [CrossRef] [PubMed]

33. Perlin, P. When crises collide: Reforming refugee law to prevent environmental degradation. Tex. Int'l LJ 2018, 53, 23. Available online: https:/ / heinonline.org/HOL/LandingPage?handle=hein.journals $/$ tilj53\&div=5\&id=\&page $=($ accessed on 29 September 2021).

34. Aregai, M.; Biedemariam, M. Human pressure and the abrupt changes on the natural environment: The case of Eritrean refugee settlements in the North western Tigray, Ethiopia. J. Arid Environ. 2019, 166, 37-42. [CrossRef]

35. Bernard, B.; Aron, M.; Loy, T.; Muhamud, N.W.; Benard, S. The impact of refugee settlements on land use changes and vegetation degradation in West Nile Sub-region, Uganda. Geocarto Int. 2020, 1-19. [CrossRef]

36. Hotelling, H. The economics of exhaustible resources. J. Polit. Econ. 1931, 39, 137-175. [CrossRef]

37. Harris, M.; Fraser, I. Natural resource accounting in theory and practice: A critical assessment. Aust. J. Agric. Econ. 2002, 46, 139-192. [CrossRef]

38. Bretschger, L. Economics of technological change and the natural environment: How effective are innovations as a remedy for resource scarcity? Ecol. Econ. 2005, 54, 148-163. [CrossRef]

39. Grissom, T.V.; McCord, M.; Mcllhatton, D.; Haran, M. The use of strong and weak form sustainability to assist in rate development for the valuation of exhaustible resources (part I). Prop. Manag. 2014, 32, 256-277.

40. Franco, M.P.; Gaspard, M.; Mueller, T. Time discounting in Harold Hotelling's approach to natural resource economics: The unsolved ethical question. Ecol. Econ. 2019, 163, 52-60. [CrossRef]

41. Dou, S.Q.; Liu, J.Y.; Xiao, J.Z.; Pan, W. Economic feasibility valuing of deep mineral resources based on risk analysis: Songtao manganese ore-China case study. Resour. Policy 2020, 66, 101612. [CrossRef] 
42. Ouoba, Y. Testing the necessary conditions for sustainability in the mining sector in Burkina Faso. Miner. Econ. 2021, 1-12. [CrossRef]

43. Alvarado, R.; Tillaguango, B.; Dagar, V.; Ahmad, M.; Işık, C.; Méndez, P.; Toledo, E. Ecological footprint, economic complexity and natural resources rents in Latin America: Empirical evidence using quantile regressions. J. Clean. Prod. 2021, $318,128585$. [CrossRef]

44. Hussain, H.I.; Haseeb, M.; Kamarudin, F.; Dacko-Pikiewicz, Z.; Szczepańska-Woszczyna, K. The Role of Globalization, Economic Growth and Natural Resources on the Ecological Footprint in Thailand: Evidence from Nonlinear Causal Estimations. Processes 2021, 9, 1103. [CrossRef]

45. Shi, S.; Hu, B.; Yan, Y.; Li, X.; Zhou, K.; Tang, C.; Xie, B. Dynamic evolution of the ecological carrying capacity of poverty-stricken karst counties based on ecological footprints: A case study in Northwestern Guangxi, China. Int. J. Environ. Res. Public Health 2020, 17, 991. [CrossRef] [PubMed]

46. Rehman, A.; Radulescu, M.; Ma, H.; Dagar, V.; Hussain, I.; Khan, M.K. The impact of globalization, energy use, and trade on ecological footprint in Pakistan: Does environmental sustainability exist? Energies 2021, 14, 5234. [CrossRef]

47. Baquié, S.; Urpelainen, J.; Khanwilkar, S.; Galletti, C.S.; Velho, N.; Mondal, P.; Nagendra, H.; DeFries, R. Migration, assets, and forest degradation in a tropical deciduous forest of South Asia. Ecol. Econ. 2021, 181, 106887. [CrossRef]

48. Badeeb, R.A.; Lean, H.H.; Shahbaz, M. Are too many natural resources to blame for the shape of the Environmental Kuznets Curve in resource-based economies? Resour. Policy 2020, 68, 101694. [CrossRef]

49. Yang, B.; Usman, M. Do industrialization, economic growth and globalization processes influence the ecological footprint and healthcare expenditures? Fresh insights based on the STIRPAT model for countries with the highest healthcare expenditures. Sustain. Prod. Consum. 2021, 28, 893-910. [CrossRef]

50. Musa, K.S.; Maijama'a, R.; Yakubu, M. The causality between urbanization, industrialization and CO2 emissions in Nigeria: Evidence from Toda and Yamamoto Approach. Energy Econ. Lett. 2021, 8, 1-14. [CrossRef]

51. Hussain, I.; Rehman, A. Exploring the dynamic interaction of CO2 emission on population growth, foreign investment, and renewable energy by employing ARDL bounds testing approach. Environ. Sci. Pollut. Res. 2021, 28, 39387-39397. [CrossRef]

52. Huber, P.J. Robust regression: Asymptotics, conjectures and Monte Carlo. Ann. Stat. 1973, 1, 799-821. [CrossRef]

53. Rousseeuw, P.J.; Yohai, V.J. Robust Regression by Means of S-Estimators. In Robust and Nonlinear Time Series; Franke, J., Härdle, W., Martin, D., Eds.; Lecture Notes in Statistics No. 26; Springer: Berlin, Germany, 1984.

54. Yohai, V.J. High breakdown-point and high efficiency robust estimates for regression. Ann. Stat. 1987, 15, 642-656. [CrossRef]

55. Naseer, A.; Su, C.W.; Mirza, N.; Li, J.P. Double jeopardy of resources and investment curse in South Asia: Is technology the only way out? Resour. Policy 2020, 68, 101702. [CrossRef]

56. Christoforidis, T.; Katrakilidis, C. The dynamic role of institutional quality, renewable and non-renewable energy on the ecological footprint of OECD countries: Do institutions and renewables function as leverage points for environmental sustainability? Environ. Sci. Pollut. Res. 2021, 28, 53888-53907. [CrossRef]

57. Anser, M.K.; Khan, M.A.; Nassani, A.A.; Aldakhil, A.M.; Hinh Voo, X.; Zaman, K. Relationship of environment with technological innovation, carbon pricing, renewable energy, and global food production. Econ. Innov. New Technol. 2020, 1-36. [CrossRef]

58. Khan, M.K.; Babar, S.F.; Oryani, B.; Dagar, V.; Rehman, A.; Zakari, A.; Khan, M.O. Role of financial development, environmentalrelated technologies, research and development, energy intensity, natural resource depletion, and temperature in sustainable environment in Canada. Environ. Sci. Pollut. Res. 2021, 1-17. [CrossRef]

59. Abbas, S.; Kousar, S.; Yaseen, M.; Mayo, Z.A.; Zainab, M.; Mahmood, M.J.; Raza, H. Impact assessment of socioeconomic factors on dimensions of environmental degradation in Pakistan. SN Appl. Sci. 2020, 2, 1-16. [CrossRef]

60. Maja, M.M.; Ayano, S.F. The Impact of Population Growth on Natural Resources and Farmers' Capacity to Adapt to Climate Change in Low-Income Countries. Earth Syst. Environ. 2021, 5, 271-283. [CrossRef] 